\title{
Effect of Olive Cake and Cactus Cladodes Incorporation in Goat Kids' Diet on the Rumen Microbial Community Profile and Meat Fatty Acid Composition
}

\author{
Samira El Otmani ${ }^{1,2, *(\mathbb{D}}$, Youssef Chebli ${ }^{1,2}{ }^{(}$, Bernard Taminiau ${ }^{3}$, Mouad Chentouf ${ }^{1}\left(\mathbb{D}\right.$, Jean-Luc Hornick ${ }^{2}(\mathbb{D})$ \\ and Jean-François Cabaraux ${ }^{2}$ (D) \\ 1 Regional Center of Agricultural Research of Tangier, National Institute of Agricultural Research, \\ Avenue Ennasr, BP 415 Rabat Principale, Rabat 10090, Morocco; youssef.chebli@inra.ma (Y.C.); \\ mouad.chentouf@inra.ma (M.C.) \\ 2 Department of Veterinary Management of Animal Resources, University of Liège, Avenue de Cureghem 6, \\ B43, 4000 Liège, Belgium; jlhornick@uliege.be (J.-L.H.); jfcabaraux@uliege.be (J.-F.C.) \\ 3 Department of Food Science, Food Microbiology, University of Liège, Avenue de Cureghem 6, B42, \\ 4000 Liège, Belgium; bernard.taminiau@uliege.be \\ * Correspondence: samira.elotmani@inra.ma
}

Citation: El Otmani, S.; Chebli, Y.; Taminiau, B.; Chentouf, M.; Hornick, J.-L.; Cabaraux, J.-F. Effect of Olive Cake and Cactus Cladodes Incorporation in Goat Kids' Diet on the Rumen Microbial Community Profile and Meat Fatty Acid Composition. Biology 2021, 10, 1237 https://doi.org/10.3390/

biology10121237

Academic Editor: Alessandra Durazzo

Received: 12 October 2021

Accepted: 25 November 2021

Published: 26 November 2021

Publisher's Note: MDPI stays neutral with regard to jurisdictional claims in published maps and institutional affiliations.

Copyright: (c) 2021 by the authors. Licensee MDPI, Basel, Switzerland. This article is an open access article distributed under the terms and conditions of the Creative Commons Attribution (CC BY) license (https:/ / creativecommons.org/licenses/by/ $4.0 /)$.
Simple Summary: Throughout the world, the ruminant diet is based on conventional feedstuffs, which their price constantly fluctuates, and their use presents a concurrence to human nutrition. The use of alternative feed resources seems to be a solution to reduce charges and diversify ruminants' diet. Olive cake and cactus cladodes are two alternative feed resources that are recommended to be used in ruminant feed. However, their effect on the bacterial community of ruminants is not widely investigated. This study aims to evaluate the effect of olive cake and cactus cladodes on the ruminal microbial ecosystem and meat fatty acids of goat kids. The incorporation of these feedstuffs did not change the bacterial abundance and diversity. Goat kids' rumen liquor seemed to be able to adapt to alternative feed resources incorporation. The introduction of olive cake and cactus cladodes slightly affect meat fatty acids without a negative effect. Thus, ruminants seem to have the ability to adapt to the alternative feed resources digestion, and their use as a feed could diversify feed and reduce feed cost.

Abstract: The olive cake (OC) and the cactus cladodes (CC) are two alternative feed resources widely available in the southern Mediterranean region that could be used in ruminants' diet. Their impact on the rumen bacterial ecosystem is unknown. This work aims to evaluate their effects on the microbial community and meat fatty acids of goat's kids. Forty-four goat kids were divided into four groups receiving diets with conventional concentrate, or $35 \%$ OC, or $30 \%$ CC, or $15 \%$ OC, and $15 \%$ CC. After 3 months, these animals were slaughtered, and the rumen liquor and longissimus dorsi and semimembranosus muscles samples were collected. Animals receiving a control diet had rumen liquor with high acidity than test groups $(p<0.001)$. Test rumen liquor was more adapted to digest efficiently their matching diet than control liquor $(p<0.05)$. These feedstuffs did not affect rumen bacteria abundance and alpha diversity (richness, evenness, and reciprocal Simpson indexes), and these results were confirmed by beta-diversity tests (NMDS plot, HOMOVA, PERMANOVA). The test diets slightly affected the individual fatty acids of meat $(p<0.05)$ without effect on fatty acids summaries, indexes, and ratios. Thus, these alternative feed resources could take place in goat kids' diet to diversify their feed and to reduce feed costs.

Keywords: olive cake; cactus cladode; goat kid; rumen liquor; microbiota; meat fatty acid

\section{Introduction}

In the harsh environment, goat (Capra hircus) livestock is the most dominant among ruminants due to their ability to adapt to dry conditions, resist diseases, and consume low- 
quality forage [1]. Goats, like all ruminants, are able to provide edible foods (meat and milk) from inedible resources for humans (forage, by-products, etc.) [2,3]. In these environments, livestock is driven in the extensive system, and its diet is based mainly on rangelands. However, the pasture forage is characterized by seasonal variability that leads to animal requirement dissatisfaction, which negatively affects livestock productivity [4]. The overuse of rangelands is one of the main drivers of ecosystem degradation that could participate in the pastoral plant species extinction $[1,4,5]$. To meet herds' requirements, farmers found themselves forced to supplement grazing by conventional feedstuffs. Their use presents a competition for human food and an additional cost for herders [6]. Researches recommend the use of unconventional feed resources to diversify ruminants' diet, valorize poor quality feed, satisfy livestock needs, and reduce feeding costs and rangeland degradation [7-9].

The introduction of alternative feedstuff in ruminants' diet devoid of negative effects on production and quality of products is a challenge for animal nutrition researchers [10]. Recently, consumers became more aware of the importance of product quality [11]. As well as their environmental impact [12], some researchers tried to improve the quality of products by introducing vegetable oils or feed with a high content of secondary compounds in order to alter digestion and to improve products contents in polyunsaturated fatty acids (PUFA) [6,7,13-17] that are beneficial to human health [11]. The alternative feedstuffs are often characterized by their content of secondary compounds (carotenoids, essential oils, antioxidants, flavors polyphenolic compounds, tocopherols, phytosterols, peptides, etc.) that could improve the meat and milk quality $[6,7,13,18]$.

The olive cake (OC) and cactus cladodes (CC) are two alternatives feed resources widely available in the Mediterranean basin, and their use in ruminants' diet is recommended by many studies that evaluate their composition and their effects on animal products $[8,9,19-21]$. These studies reported most of the time lack of negative effect on production, and often the improvement of products' quality [22-25]. However, the incorporation of OC affects milk and meat quality by increasing linoleic acid contents and improving fatty acids profile [26-28]. In addition, Mahouachi et al. [21] reported an effect of CC on that products' quality that could be related to digestion and microbiota because PUFA content in animals' products results from rumen biohydrogenation shifting. The drivers of FA biohydrogenation in the rumen are mainly bacteria from the Butyrivibrio genus [29]. It is known that the growth of Butyrivibrio fibrisolvens, one of the FA biohydrogenation bacteria, is inhibited by secondary compounds such as condensed tannins [30]. Thus, it is interesting to investigate the effect of OC and CC on the bacterial community. To our knowledge, studies evaluating the effect of these alternative feed resources on small ruminants are very limited. Previous studies on the effect of OC incorporation on the bacterial community of rumen have only been conducted upon sheep and dairy ewes [14,16,31]. However, the OC effect on the ruminal ecosystem of goat kids has never been studied before. While for CC incorporation effect on the bacterial community of rumen, no studies investigating this alternative feed resource have been already published until now. Thereby, the impact of these two unconventional feed resources on the rumen bacterial ecosystem, especially of goats, has never been investigated before. Among ruminants, the ruminal ecosystem of this species is able to degrade lignin and tannins-rich feedstuffs $[15,22,32,33]$. In this context, this work aims to evaluate the effect of OC and CC incorporation on ruminal bacteria diversity and meat fatty acids.

\section{Materials and Methods}

\subsection{Animals and Diets}

This experiment was performed in the experimental farm of the Regional Center of Agricultural Research of Tangier (INRA-Morocco) that is located at $35^{\circ} 67^{\prime} \mathrm{N}$ and $5^{\circ} 85^{\prime} \mathrm{W}$. On this farm, the goat herd is of Beni Arouss Breed. This is a North Moroccan indigenous breed, well adapted to the local conditions. It is characterized by a red coat and an average bodyweight of about 42 and $38 \mathrm{~kg}$ for males and females, respectively [34], and an average milk production of about $600 \mathrm{~mL} /$ day during a lactation period of three months [35]. In 
the experiment, forty-four male goat kids of Beni Arouss, with an initial body weight of $10.5 \pm 0.1 \mathrm{~kg}$, aged three months were divided into four groups on a bodyweight basis and individually housed. During the three months of the experiment, all groups received oat hay complemented by a concentrate diet. As shown in Table 1, which presents the distributed diets and their chemical composition and nutritive value, the control group received a conventional concentrate based on barley as a source of energy and faba bean as a nitrogen source, as used by the local breeders. The other test groups received a concentrate with OC and/or CC of Opuntia ficus indica in addition to faba beans. The concentrate of the first test group ( $\mathrm{T}_{\mathrm{oc}}$ ) contained $35 \%$ of $\mathrm{OC}$, and $30 \%$ of CC was incorporated in the second test group $\left(\mathrm{T}_{\mathrm{cc}}\right)$ diet. The last group $\left(\mathrm{T}_{\mathrm{oc}+\mathrm{cc}}\right)$ had an administration of $15 \%$ of both (Figure 1 ). The OC was obtained from olive oil mills that used mechanical press process, located in Ouazzane town in Northern Morocco during the period of oil extraction (November to January). The crude $\mathrm{OC}$ was dried under a plastic greenhouse and conserved in plastic bags in hermetic conditions until the experiment. As for CC, they were provided daily from shrubs nearly installed. The spines of CC were manually removed, and cladodes were manually cut to slides of $9 \mathrm{~cm}^{2}$. The ingredients of the diet were ground and mixed to be distributed two times per day. The offered rations were adapted to allow $10 \%$ of orts that were quantified daily to determine the dry matter intake (DMI) as described by Palmieri et al. [36].

\subsection{Slaughter and Sampling}

After 3 months of the experiment, the animals were slaughtered, as detailed by El Otmani et al. [9]. The use of the animals and the experimental procedure were approved by the Regional Center of Agricultural Research of Tangier, Morocco (permit number 01/CRRAT/2017). After slaughter, rumen liquor was collected and sieved using a double cheese filter. Immediately, the rumen liquor $\mathrm{pH}$ was measured using a $\mathrm{pH}$ meter pen (HANNA HI 98120), and $1 \mathrm{~L}$ of rumen liquor of each group of animals was conducted in a pre-warmed thermos at $40^{\circ} \mathrm{C}$ to the laboratory to be used in diets digestibility. For DNA extraction, $100 \mathrm{~mL}$ of each animal liquor sample was conserved at $-80^{\circ} \mathrm{C}$. In addition, the longissimus dorsi and semimembranosus muscles of each carcass were removed to determine the fatty acids of goat meat.

Table 1. Ingredients, chemical, and nutritive composition of goat kids' diets.

\begin{tabular}{|c|c|c|c|c|}
\hline \multirow{2}{*}{ Item } & \multicolumn{4}{|c|}{ Diet $^{1}$} \\
\hline & Co & $\mathbf{T}_{\mathrm{OC}}$ & $\mathbf{T}_{\mathrm{CC}}$ & $\mathrm{T}_{\mathrm{OC}+\mathrm{CC}}$ \\
\hline \multicolumn{5}{|l|}{ Diet ingredients (on DM basis) $^{2}$} \\
\hline Oat hay $(\mathrm{g} / \mathrm{kg} \mathrm{TD})$ & 508 & 427 & 466 & 456 \\
\hline Barley (g/kg CD) & 390 & 0 & 0 & 0 \\
\hline Olive cake (g/kg CD) & 0 & 350 & 0 & 150 \\
\hline Cactus cladodes (g/kg CD) & 0 & 0 & 300 & 150 \\
\hline Faba beans $(\mathrm{g} / \mathrm{kg} \mathrm{CD})$ & 590 & 630 & 680 & 680 \\
\hline Vitamin-mineral supplement (g/kg CD) & 20 & 20 & 20 & 20 \\
\hline \multicolumn{5}{|l|}{ Chemical composition of diet } \\
\hline Dry matter (DM; g/kg CM) & 885 & 887 & 292 & 435 \\
\hline Ash (g/kg DM) & 47 & 47 & 77 & 62 \\
\hline Crude protein (CP; g/kg DM) & 140 & 155 & 150 & 154 \\
\hline Ether extract (EE; g/kg DM) & 35 & 60 & 33 & 44 \\
\hline Neutral detergent fiber (NDF; g/kg DM) & 446 & 480 & 456 & 467 \\
\hline Acid detergent fiber (ADF; g/kg DM) & 273 & 328 & 276 & 300 \\
\hline Metabolizable energy (ME; MJ / kg DM) & 12 & 10 & 11 & 11 \\
\hline Forage unit for meat (FUMeat/kg DM) & 0.8 & 0.7 & 0.7 & 0.7 \\
\hline Digestible proteins in the intestines (DPI; g/kg DM) & 75 & 63 & 69 & 67 \\
\hline
\end{tabular}

${ }^{1}$ Co: control diet; $\mathrm{T}_{\mathrm{OC}}$ : diet with $35 \%$ of olive cake; $\mathrm{T}_{\mathrm{CC}}$ : diet with $30 \%$ of cactus cladodes; $\mathrm{T}_{\mathrm{OC}+\mathrm{CC}}$ : diet with $15 \%$ of olive cake and $15 \%$ of cactus cladodes. ${ }^{2}$ TD: total diet; CD: concentrate diet; CM: crude matter. 


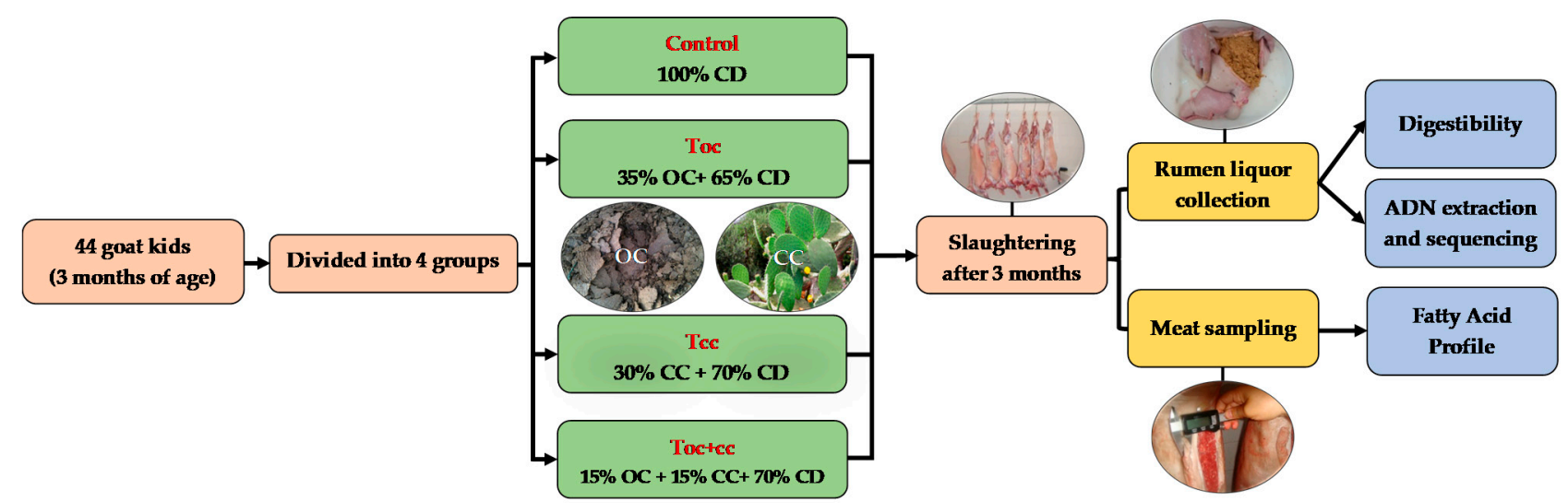

Figure 1. Experimental protocol scheme. CD: conventional concentrate diet (barley and faba bean); OC: olive cake; CC: cactus cladodes. $\mathrm{T}_{\mathrm{OC}}$ : $\mathrm{CD}$ with $35 \%$ of olive cake; $\mathrm{T}_{\mathrm{CC}}$ : $\mathrm{CD}$ with $30 \%$ of cactus cladodes; $\mathrm{T}_{\mathrm{OC}+\mathrm{CC}}$ : CD with $15 \%$ of olive cake and $15 \%$ of cactus cladodes.

\subsection{Diets' In Vitro Digestibility}

The efficiency of groups of rumen liquor was evaluated by comparing the in vitro digestibility of dry (IVDMD) and organic matter (IVOMD) of control and test diets using control and test groups of rumen liquor. The IVDMD and IVOMD were performed using Ankom Daisy II Incubator ${ }^{\circledR}$ (ANKOM Technology, Fairport, NY, USA) as described by Mabjeesh et al. [37]. Briefly, filter bags with $500 \mathrm{mg}$ of diet samples were incubated in rumen inoculums and buffer (1:4 ratio) at $39^{\circ} \mathrm{C}$ in anaerobic conditions for $48 \mathrm{~h}$. In the control group, rumen liquor, all experimental diets were incubated; however, in each test group, rumen liquor, control diet, and the corresponding liquor diet were incubated. In the end, the residual DM and OM were quantified to determine IVDMD and IVOMD.

\subsection{Microbiota Analysis}

\subsubsection{DNA Extraction}

Before DNA extraction, rumen liquor was freeze-dried using benchtop freeze dryer OPERON FDB-5502. The DNA extraction was performed according to Yu and Morrison [38]. Briefly, cell lysis was performed on $0.25 \mathrm{~g}$ of samples using a lysis buffer $(500 \mathrm{mM}$ of $\mathrm{NaCl}, 50 \mathrm{mM}$ of Tris- $\mathrm{HCl}, \mathrm{pH} 8$, EDTA $50 \mathrm{mM}$, sodium dodecyl sulfate at $4 \%$ SDS) and zirconia beads $\left(0.1\right.$ and $0.5 \mathrm{~mm}$ ) at $70{ }^{\circ} \mathrm{C}$ during $15 \mathrm{~min}$ and centrifugation at $4{ }^{\circ} \mathrm{C}$. The procedure of lysis was performed two times, and the supernatants were recuperated. The precipitation of nucleic acids was realized with $10 \mathrm{M}$ ammonium acetate and isopropanol. Nucleic acids were washed with $70 \%$ of ethanol and dissolved in $100 \mu \mathrm{L}$ of Tris-EDTA buffer (TE, Tris $50 \mathrm{mM}$, EDTA $50 \mathrm{mM}$ ). The DNA was purified, and RNA and proteins were eliminated by incubation with DNase-free RNase and proteinase $\mathrm{K}$ and using a Qiagen extraction kit (QIAamp DNA Micro Kit 50). The extracted DNA was conserved at $-20^{\circ} \mathrm{C}$. To verify the quality of DNA, an electrophorese was performed on $1.2 \%$ agarose gel using Tris Borate EDTA buffer ( $89 \mathrm{mM}$ Tris, $89 \mathrm{mM}$ boric acid, $2 \mathrm{mM}$ EDTA, TBE 10X pH 8.3) and a fluorescent colorant (Bioline 5X DNA loading buffer) with a horizontal box (Enduro Electrophoresis Systems-Labnet International, Inc. E1010-10) in $70 \mathrm{~V}$ during $40 \mathrm{~min}$. The DNA visualization was carried out by Vilbert Lourmat TM Ebox TM VX2 imagins system.

\subsection{2. $16 \mathrm{~S}$ rRNA Gene Library Construction and Sequencing}

The V1-V3 region of $16 \mathrm{~S}$ rDNA of each sample was amplified using (5'-GAGAGTTTGA TYMTGGCTCAG-3 ${ }^{\prime}$ ) and reverse ( $5^{\prime}$-ACCGCGGCTGCTGGCAC-3') primers with Illumina overhand adapters before purification with the Agencourt AMPure XP beads kit (Beckman Coulter, Pasadena, CA, USA). For indexing, a second PCR round was performed with the primers 1 and 2 of the Nextera XT index. After purification, Quant-IT PicoGreen (Thermo Fisher Scientific, Waltham, MA, USA) was used to quantify each sample, and finale quantifi- 
cation was carried out with KAPA SYBR ${ }^{\circledR}$ FAST qPCR Kit (KapaBiosystems, Wilmington, NC, USA). The PCR products were normalized, pooled, and sequenced by MiSeq sequencer using v3 reagents (ILLUMINA, San Diego, CA, USA). The MOTHUR software package v1.39.5 [39,40] was used to align, classify and cluster sequences into operation taxonomic unit (OTU) (average neighbor algorithm) and VSEARCH algorithm [41] to and detect and remove chimera sequences. The SILVA database (v1.32) was used as a reference for fulllength $16 \mathrm{~S}$ rDNA sequences alignment and taxonomical assignation [42]. For microbiota structure and composition analysis, a subsamples table with 10,000 sequences/samples were obtained.

\subsection{Meat Fatty Acid}

Samples of longissimus dorsi and semimembranosus muscles were collected directly after slaughter and ground to determine the fatty acids of goat meat, according to Mioč et al. [43]. The intramuscular fat was extracted using chloroform-methanol according to Folch et al. [44] method. The fatty acids methyl esters were prepared using the AOAC [45] method before their conservation in a $-80^{\circ} \mathrm{C}$ freezer. These fatty acids were identified by injecting in GC (Varian GC CP 3800) equipped with a flame ionization detector and a capillary column type CP-SIL88 capillary column $(100 \mathrm{~m} \times 0.25 \mathrm{~mm} \times 0.2 \mu \mathrm{m})$, and compared to a standard analytical mixture of C4 to C24 FA (FAME Sigma-Aldrich, St. Louis, MO, USA) referring to 37 FA.

\subsection{Data Analysis}

The meat fatty acids were compared according to a mixed model, including the random effect animal (PROC MIXED; SAS 9.4). The effects of diet on liquor $\mathrm{pH}$ and of rumen liquor on diets digestibility were tested by one-way analysis of variance (ANOVA).

Bacterial data were summarized by phylum and genus, and alpha and beta diversity were determined. The studied parameters were Good's coverage estimator, observed species, Chao1 richness index, reciprocal Simpson index, and Simpson evenness index at the genus and species levels using MOTHUR.

The effect of diet on different bacterial community abundance was estimated with a non-parametric Kruskal-Wallis H tests corrected with a Storey false discovery rate followed by Tukey-Kramer post-hoc test (STAMP 2.1.3 software). Multiple comparisons of the means were performed when a significant effect was obtained at p-value less than 0.05 using the Dunnett test.

Nonmetric multidimensional scaling (nMDS) plot, homogeneity of molecular variance (HOMOVA), and permutational multivariate analysis of variance (PERMANOVA) using Bray-Curtis dissimilarity matrix and permutation of 10,000 were performed to evaluate beta diversity.

In the case of a significant effect was obtained at $p$-value $<0.05$, means were compared using Tukey's test.

\section{Results}

The dry matter intake was variable between 854 and $1016 \mathrm{~kg} /$ day. This parameter was statistically similar for all groups with an average of $938 \mathrm{~kg} /$ day $(p=0.30)$.

The rumen liquor $\mathrm{pH}$ of goat kids was very highly affected by diet $(p<0.001)$. With $\mathrm{pH}$ 5.7, the control liquor was more acid than all test groups (Figure 2). Other test groups liquor had a $\mathrm{pH}$ of $6.09,6.22$, and 6.21 , respectively, for $\mathrm{T}_{\mathrm{oc}}, \mathrm{T}_{\mathrm{cc}}$, and $\mathrm{T}_{\mathrm{oc}+\mathrm{cc}}$.

The IVDDM and IVDOM of the control diet were the same using the control and the test groups rumen liquor (Table 2). However, test diets were more digestible by their own rumen liquor compared to the control $(p<0.05)$. The IVDDM and IVDOM of $\mathrm{T}_{\mathrm{oc}+\mathrm{cc}}$ were higher with its inoculum than control in a very highly significant way $(p<0.001)$. 


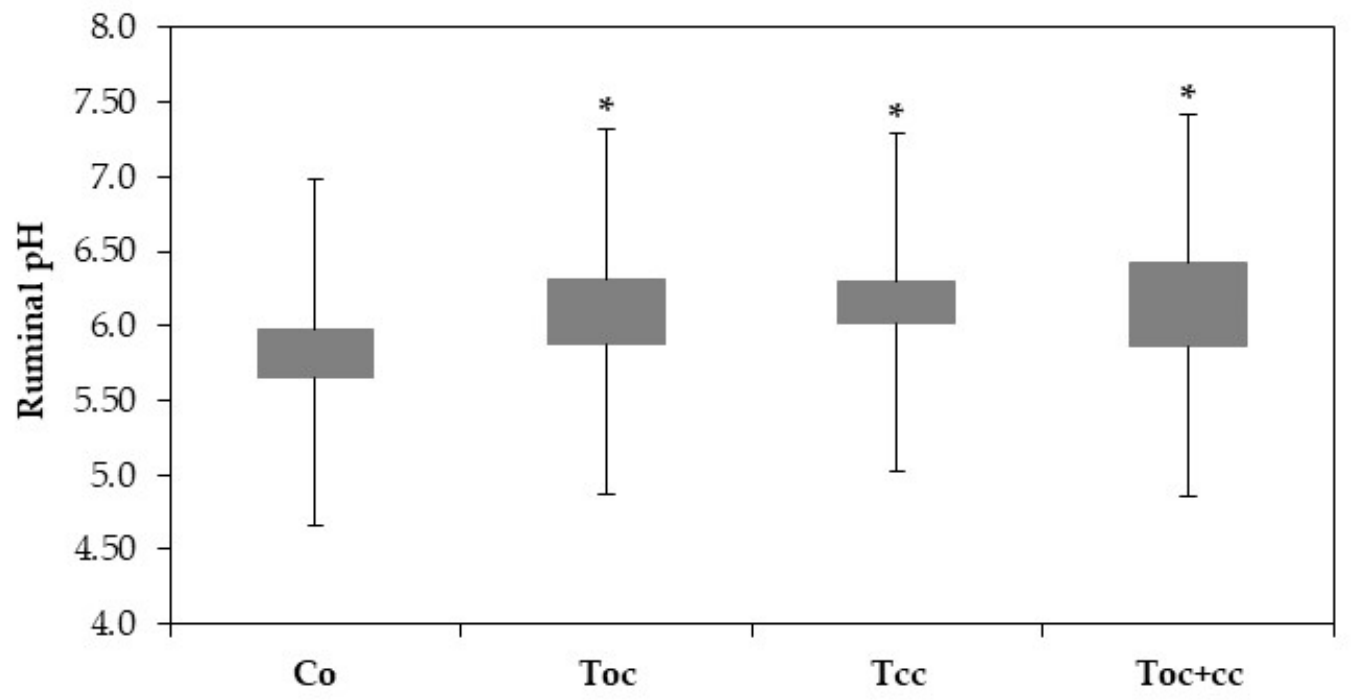

Figure 2. Ruminal $\mathrm{pH}$ of goat kids according to diets. Co: control; $\mathrm{T}_{\mathrm{OC}}: 35 \%$ olive cake; $\mathrm{T}_{\mathrm{CC}}$ : $30 \%$ cactus cladodes; $\mathrm{T}_{\mathrm{OC}+\mathrm{CC}}: 15 \%$ olive cake $+15 \%$ cactus cladodes; ${ }^{*}$ : groups with * are significantly different from the Co group at $p<0.05$.

Table 2. In vitro dry and organic matter digestibility of control and test diets incubated in different groups' rumen liquor.

\begin{tabular}{|c|c|c|c|c|}
\hline Diet & Rumen Liquor & $\mathbf{n}$ & IVDMD & IVOMD \\
\hline \multirow{6}{*}{$\mathrm{Co}$} & $\mathrm{Co}$ & 18 & 0.560 & 0.540 \\
\hline & $\mathrm{T}_{\mathrm{OC}}$ & 6 & 0.596 & 0.575 \\
\hline & $\mathrm{T}_{\mathrm{CC}}$ & 6 & 0.627 & 0.611 \\
\hline & $\mathrm{T}_{\mathrm{OC}+\mathrm{CC}}$ & 6 & 0.585 & 0.564 \\
\hline & SEM & & 0.012 & 0.013 \\
\hline & $p$-value & & 0.242 & 0.246 \\
\hline \multirow{4}{*}{$\mathrm{T}_{\mathrm{oc}}$} & Co & 10 & $0.459^{b}$ & $0.436^{b}$ \\
\hline & $\mathrm{T}_{\mathrm{OC}}$ & 20 & $0.510^{\mathrm{a}}$ & $0.489^{a}$ \\
\hline & SEM & & 0.013 & 0.013 \\
\hline & $p$-value & & 0.021 & 0.022 \\
\hline \multirow{4}{*}{$\mathrm{T}_{\mathrm{cc}}$} & Co & 10 & $0.571^{b}$ & $0.531^{\mathrm{b}}$ \\
\hline & $\mathrm{T}_{\mathrm{CC}}$ & 20 & $0.607^{\mathrm{a}}$ & $0.571^{\mathrm{a}}$ \\
\hline & SEM & & 0.008 & 0.009 \\
\hline & $p$-value & & 0.032 & 0.027 \\
\hline \multirow{4}{*}{$\mathrm{T}_{\mathrm{OC}+\mathrm{cc}}$} & Co & 10 & $0.509^{b}$ & $0.477^{b}$ \\
\hline & $\mathrm{T}_{\mathrm{OC}+\mathrm{CC}}$ & 20 & $0.585^{\mathrm{a}}$ & $0.555^{\mathrm{a}}$ \\
\hline & SEM & & 0.009 & 0.009 \\
\hline & $p$-value & & $<0.001$ & $<0.001$ \\
\hline
\end{tabular}

IVDMD: in vitro dry matter digestibility; IVOMD: in vitro organic matter digestibility; Co: control diet; $\mathrm{T}_{\mathrm{OC}}$ : diet with $35 \%$ of olive cake; $\mathrm{T}_{\mathrm{CC}}$ : diet with $30 \%$ of cactus cladodes; $\mathrm{T}_{\mathrm{OC}+\mathrm{CC}}$ : diet with $15 \%$ of olive cake and $15 \%$ of cactus cladodes; SEM: standard error of mean; ${ }^{\mathrm{a}, \mathrm{b}}$ : values followed by different letters are significantly different at $p<0.05$.

From the normalized OTU table, it has been revealed 21 phyla, 38 classes, 78 orders, 125 families, 278 genera, and 8088 species of bacteria in the rumen liquor. Table 3 presents the studied parameters of alpha diversity at the genus and species levels. The sequencing of rumen liquor permitted to identify $99.8 \%$ and $93.9 \%$ of the nucleotide sequence in all groups at genus and species levels, respectively. The alpha-diversity parameters were similar in all rumen liquors. With each diet, observed species were stable with an average of 116.5 genera and 1254 species. The richness estimated by the Chao1 index did not differ in the test groups compared to the control. The evenness deduced by the Simpson index was similar in all groups with 0.06 in the control and $\mathrm{T}_{\mathrm{oc}}$, and 0.07 in $\mathrm{T}_{\mathrm{cc}}$ and $\mathrm{T}_{\mathrm{oc}+\mathrm{cc}}$ groups at the genus level and $0.021,0.034,0.047$, and 0.042 , respectively, in the control group, 
$\mathrm{T}_{\mathrm{oc}}, \mathrm{T}_{\mathrm{cc}}$, and $\mathrm{T}_{\mathrm{oc}+\mathrm{cc}}$ at the species level. No significant differences were observed between groups for the inverse Simpson index at the genus and species levels. Bacterial community composition was evaluated at three taxonomic levels. At the phylum level, the most dominant phyla were Bacteriodetes, Firmicutes, and Proteobacteria (Figure 3). Bacteriodetes abundance ranged from $42 \%$ in $\mathrm{T}_{\mathrm{cc}}$ to $49 \%$ in $\mathrm{T}_{\mathrm{oc}}$ liquor. The rumen liquor of $\mathrm{Co}$ and $\mathrm{T}_{\mathrm{oc}+\mathrm{cc}}$ contained $47 \%$ of Bacteriodetes. The Firmicutes presented an average of $33 \%$ of phyla in goat kids rumen liquor. The abundance of Proteobacteria was $7 \%, 9 \%, 15 \%$, and $20 \%$ in $\mathrm{T}_{\mathrm{oc}}$, $\mathrm{T}_{\mathrm{cc}}, \mathrm{T}_{\mathrm{oc}+\mathrm{cc}}$, and Co liquor, respectively. Even their numerical variation, distributed diets were without an effect on the abundance of all phyla (Table 3). However, the incorporation of $35 \%$ OC and $30 \%$ CC trend to reduce the Proteobacteria phylum compared to control $(p<0.1)$. The Firmicutes/Bacteriodetes ratio was similar between groups even the average variability $\left(1.26,7.29,1.58\right.$, and $4.56 \mathrm{in} \mathrm{Co}, \mathrm{T}_{\mathrm{oc}}, \mathrm{T}_{\mathrm{cc}}$, and $\mathrm{T}_{\mathrm{oc}+\mathrm{cc}}$, respectively). At the bacterial family's level, the most dominant microbiotas were from five families that were Prevotellaceae, Ruminococcaceae, Succinivibrionaceae, Lachnospiraceae, and Rikenellaceae (Figure 4). The abundance of Prevotellaceae ranged between $39 \%$ in $\mathrm{T}_{\mathrm{oc}}$ and $28 \%$ in $\mathrm{T}_{\mathrm{cc}}$. The family of Ruminococcaceae was $11 \%, 14 \%, 20 \%$, and $21 \%$ in the liquor of $\mathrm{Co}, \mathrm{T}_{\mathrm{oc}+\mathrm{cc}}, \mathrm{T}_{\mathrm{oc}}$, and $\mathrm{T}_{\mathrm{cc}}$, respectively. The Succinivibrionaceae, Lachnospiraceae, and Rikenellaceae accounted for $12.5 \%$, $7.3 \%$, and $6.6 \%$ of total bacterial abundance, respectively. Despite the variable values of the dominant families' abundance, they were similar in all groups. However, the richness of Defluviitaleaceae was significantly increased by the administration of $30 \%$ CC $(p<0.05)$. The Fusobacteriaceae and NED5E9 fa tended to be affected by diet $(p<0.1)$. The Fusobacteriaceae was significantly higher in $\mathrm{T}_{\mathrm{oc}+\mathrm{cc}}(p<0.05)$. The administration of $\mathrm{CC}$ in the diet of $\mathrm{T}_{\mathrm{cc}}$ and $\mathrm{T}_{\mathrm{oc}+\mathrm{cc}}$ tended to increase the importance of NED5E9 $\mathrm{fa}(p<0.1)$. At the genera level, Prevotella_1 was the most dominant genus with an average abundance of $26 \%$. The abundance of this genus was the same in all groups (Table 4). The Defluviitaleaceae_UCG_011, Aeriscardovia, and Lachnospiraceae_NK4B4_group were affected by diet $(p<0.05)$. The content of Aeriscardovia was significantly lower in the test groups compared to the control. The incorporation of 35\% OC increased Lachnospiraceae_NK4B4_group content. While Defluviitaleaceae_UCG_011 had been enriched in rumen liquor by 30\% CC incorporation. The distributed diets tended to affect Butyrivibrio_2, Marvinbryantia, Howardella genera belonging to the Lachnospiraceae family, Fusobacterium, Atopobiaceae_ge, Selenomonas_1, NED5E9_ge, and Ruminococcaceae_UCG-001 $(p<0.1)$. Compared to control, the incorporation of 35\% OC tended to increase Butyrivibrio_2, Atopobiaceae, and Ruminococcaceae_UCG-001 and to decrease Howardella. However, 30\% of CC administration tended to increase Marvinbryantia, Atopobiaceae_ge, NED5E9_ge, and Ruminococcaceae_UCG-001 and to reduce Howardella and Selenomonas_1 compared to the control. The OC and CC combination tended to increase Fusobacterium, Atopobiaceae_ge, and NED5E9_ge and to decrease Howardella, Selenomonas_1, and Ruminococcaceae_UCG-001 contents. The beta diversity was evaluated using the nonmetric multidimensional scaling plot (nMDS with three axes, Figure 5), and homogeneity of molecular variance (HOMOVA), and permutational analysis of variance (PERMANOVA). According to nMDS (Figure 5), it is clear that there is a variation in each cluster of points. All clusters are overlapped with each other except for one animal of the $T_{\mathrm{oc}+c \mathrm{cc}}$ group, which means that all groups are similar, and the inclusion of alternative feedstuffs did not significantly affect the beta diversity. Thus, the microbiota composition was not altered by OC and CC administration, except for one sample of the $\mathrm{T}_{\mathrm{oc}+\mathrm{cc}}$ group that was projected outside. The HOMOVA $(p=0.514)$ and PERMANOVA $(F=1.03 ; p=0.349)$ showed no difference between groups according to distributed diet.

As detailed in Table 5 , the incorporation of $\mathrm{OC}$ in $\mathrm{T}_{\mathrm{oc}}$ increased significantly undecylic (C11:0), and docosadienoic (C22:2) acids and decreased lauric (C12:0) and selacholeic (C24:1) acids $(p<0.05)$. However, OC administration tended to increase elaidic (9t-C18:1) acid $(p<0.1)$. In the intramuscular fat, C12:0 and C24:1 decreased significantly by CC introduction in the $\mathrm{T}_{\mathrm{CC}}$ group $(p<0.05)$. The arachidic acid (C20:0) tended to increase, and the 9t-C18:1 and docosahexaenoic (C22:6n-3; DHA) had a tendency to decrease with CC inclusion $(p<0.1)$. The inclusion of both of the alternative feeds in the goat kids' diet 
of $\mathrm{T}_{\mathrm{oc}+\mathrm{cc}}$ increased significantly C22:2 and decreased C12:0 and C24:1 $(p<0.05)$. For FA groups, they were not affected significantly by alternative feedstuffs inclusion. However, the OC incorporation with or without CC tended to increase $n-3$, and the CC inclusion tended to decrease PUFA $(p<0.1)$. Comparatively to FA groups, FA ratios and indexes were statistically similar in all studied animals' groups. Nevertheless, $($ C18:0 + C18:1)/C16:0 index tended to be affected by OC and/or CC incorporation with a decreased tendency in the CC group $(p<0.1)$.

Table 3. Alpha diversity of microbiota genus and species according to diet.

\begin{tabular}{ccccccc}
\hline Iterm & Co & $\mathbf{T}_{\mathbf{O C}}$ & $\mathbf{T}_{\mathbf{C C}}$ & $\mathbf{T}_{\text {OC+CC }}$ & $p$-Value & SEM \\
\hline Genus & & & & & & \\
Good's coverage estimator (\%) & 99.78 & 99.79 & 99.79 & 99.77 & 0.581 & 0.006 \\
Observed genus & 115.11 & 115.60 & 119.19 & 115.91 & 0.956 & 3.051 \\
Chao1 & 134.10 & 135.65 & 138.70 & 138.75 & 0.964 & 3.625 \\
Inverse Simpson index & 7.00 & 6.62 & 9.12 & 9.04 & 0.479 & 0.707 \\
Simpson evenness index & 0.058 & 0.057 & 0.074 & 0.071 & 0.516 & 0.005 \\
$\quad$ Species & & & & & & \\
Good's coverage estimator (\%) & 93.20 & 94.45 & 93.61 & 94.42 & 0.481 & 0.315 \\
$\quad$ Observed species & 1352 & 1162 & 1358 & 1144 & 0.464 & 61.8 \\
$\quad$ Chao1 & 2353 & 1950 & 2269 & 1945 & 0.434 & 105.1 \\
Inverse Simpson index & 29.20 & 47.23 & 67.17 & 59.96 & 0.508 & 9.36 \\
Simpson evenness index & 0.021 & 0.034 & 0.047 & 0.043 & 0.393 & 0.0057 \\
\hline
\end{tabular}

Co: control; $\mathrm{T}_{\mathrm{oc}}: 35 \%$ olive cake; $\mathrm{T}_{\mathrm{cc}}: 30 \%$ cactus cladodes; $\mathrm{T}_{\mathrm{oc}+\mathrm{cc}}: 15 \%$ olive cake $+15 \%$ cactus cladodes SEM: standard error of mean.
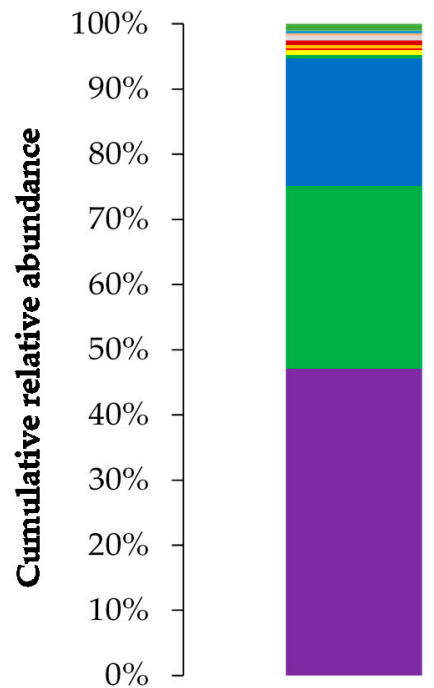

Co

- Others $(<0.5 \%)$

- Cyanobacteria

- Chloroflexi

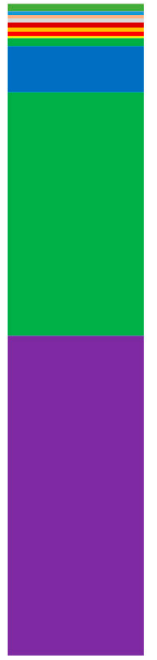

Toc

- Kiritimatiellaeota

- Fibrobacteres

- Proteobacteria

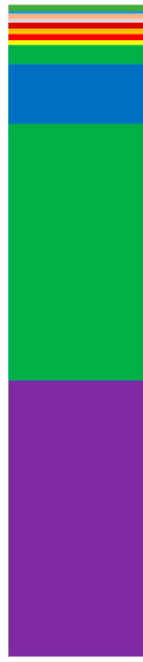

Tcc

Patescibacteria

- Actinobacteria

- Firmicutes

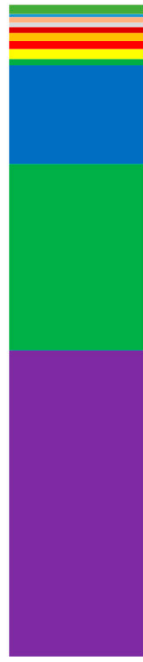

Toc + cc

Lentisphaerae

Spirochaetes

- Bacteroidetes

Figure 3. Cumulative relative abundance of bacterial community phylum according to distributed diet. Co: control; $\mathrm{T}_{\mathrm{oc}}: 35 \%$ olive cake; $\mathrm{T}_{\mathrm{cc}}: 30 \%$ cactus cladodes; $\mathrm{T}_{\mathrm{oc}+\mathrm{cc}}: 15 \%$ olive cake $+15 \%$ cactus cladodes. 


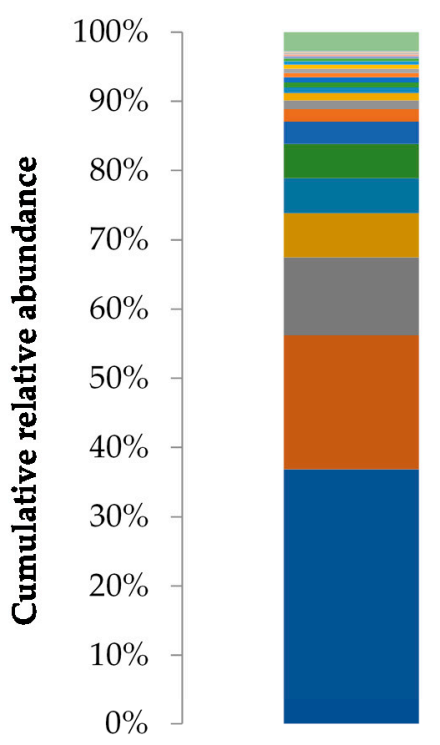

Co

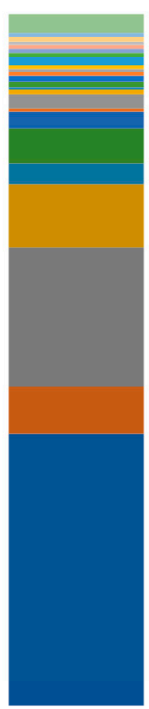

Toc

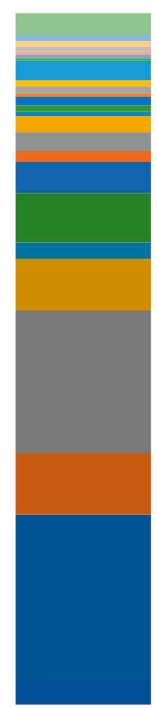

Tcc

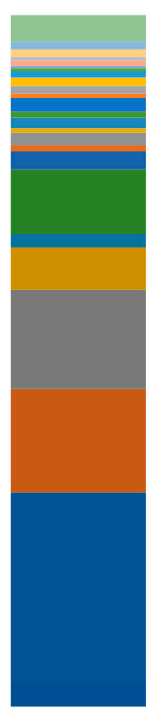

Toctcc
Other families
- Bifidobacteriaceae
Actinobacteria_fa
Erysipelotrichaceae
- Clostridiales_Family_XIII
- Bacteroidales_UCG-001
- Fibrobacteraceae
- Gastranaerophilales fa
- Muribaculaceae
- Spirochaetaceae
- Christensenellaceae
- Ruminococcaceae
CHB1-41
- vadinBE97
- Acidaminococcaceae
- Rikenellaceae
- Succinivibrionaceae

Figure 4. Cumulative relative abundance of bacterial community families according to distributed diet. Co: control; $\mathrm{T}_{\mathrm{oc}}: 35 \%$ olive cake; $\mathrm{T}_{\mathrm{cc}}: 30 \%$ cactus cladodes; $\mathrm{T}_{\mathrm{oc}+\mathrm{cc}}: 15 \%$ olive cake $+15 \%$ cactus cladodes.

Table 4. Diet effect on the relative abundance of some bacterial community genus.

\begin{tabular}{|c|c|c|c|c|c|c|c|}
\hline Family & Genus & Co & $\mathbf{T}_{\mathbf{o c}}$ & $\mathbf{T}_{\mathrm{cc}}$ & $\mathbf{T}_{\mathrm{oc}+\mathrm{cc}}$ & SEM & $p$-Value \\
\hline & & $\mathbf{n}=\mathbf{1 1}$ & $\mathbf{n}=\mathbf{1 1}$ & $\mathbf{n}=\mathbf{1 1}$ & $\mathbf{n}=\mathbf{1 1}$ & & \\
\hline Defluviitaleaceae & Defluviitaleaceae_UCG_011 & $0.017^{\mathrm{b}}$ & $0.027^{a b}$ & $0.037^{\mathrm{a}}$ & $0.012^{b}$ & 0.005 & 0.015 \\
\hline \multirow{5}{*}{ Lachnospiraceae } & Butyrivibrio_2 & 0.204 & 0.377 & 0.159 & 0.225 & 0.031 & 0.082 \\
\hline & Howardella & 0.082 & 0.043 & 0.054 & 0.008 & 0.016 & 0.076 \\
\hline & Lachnoclostridium_10 & 0.023 & 0.032 & 0.058 & 0.022 & 0.008 & 0.246 \\
\hline & Lachnospiraceae_NK4B4_group & $0.000^{b}$ & $0.005^{\mathrm{a}}$ & $0.001^{b}$ & $0.000^{b}$ & 0.0006 & 0.044 \\
\hline & Marvinbryantia & 0.142 & 0.157 & 0.237 & 0.098 & 0.022 & 0.067 \\
\hline Fusobacteriaceae & Fusobacterium & 0.000 & 0.000 & 0.000 & 0.002 & 0.0003 & 0.052 \\
\hline Bifidobacteriaceae & Aeriscardovia & $0.012^{\mathrm{a}}$ & $0.000^{b}$ & $0.001^{b}$ & $0.000^{b}$ & 0.0016 & 0.044 \\
\hline Atopobiaceae & Atopobiaceae_ge & 0.010 & 0.039 & 0.029 & 0.042 & 0.007 & 0.096 \\
\hline \multirow[b]{2}{*}{ Veillonellaceae } & Anaerovibrio & 0.011 & 0.025 & 0.008 & 0.011 & 0.003 & 0.128 \\
\hline & Selenomonas_1 & 0.346 & 0.372 & 0.182 & 0.171 & 0.038 & 0.098 \\
\hline NED5E9_fa & NED5E9_ge & 0.000 & 0.000 & 0.002 & 0.007 & 0.001 & 0.057 \\
\hline Ruminococcaceae & Ruminococcaceae_UCG-001 & 0.029 & 0.072 & 0.047 & 0.007 & 0.018 & 0.095 \\
\hline
\end{tabular}

Co: control; $\mathrm{T}_{\mathrm{oc}}: 35 \%$ olive cake; $\mathrm{T}_{\mathrm{cc}}: 30 \%$ cactus cladodes; $\mathrm{T}_{\mathrm{oc}+\mathrm{cc}}: 15 \%$ olive cake $+15 \%$ cactus cladodes; SEM: standard error of mean;

${ }^{\mathrm{a}, \mathrm{b}}$ : values followed by different letters are significantly different at $p<0.05$. 


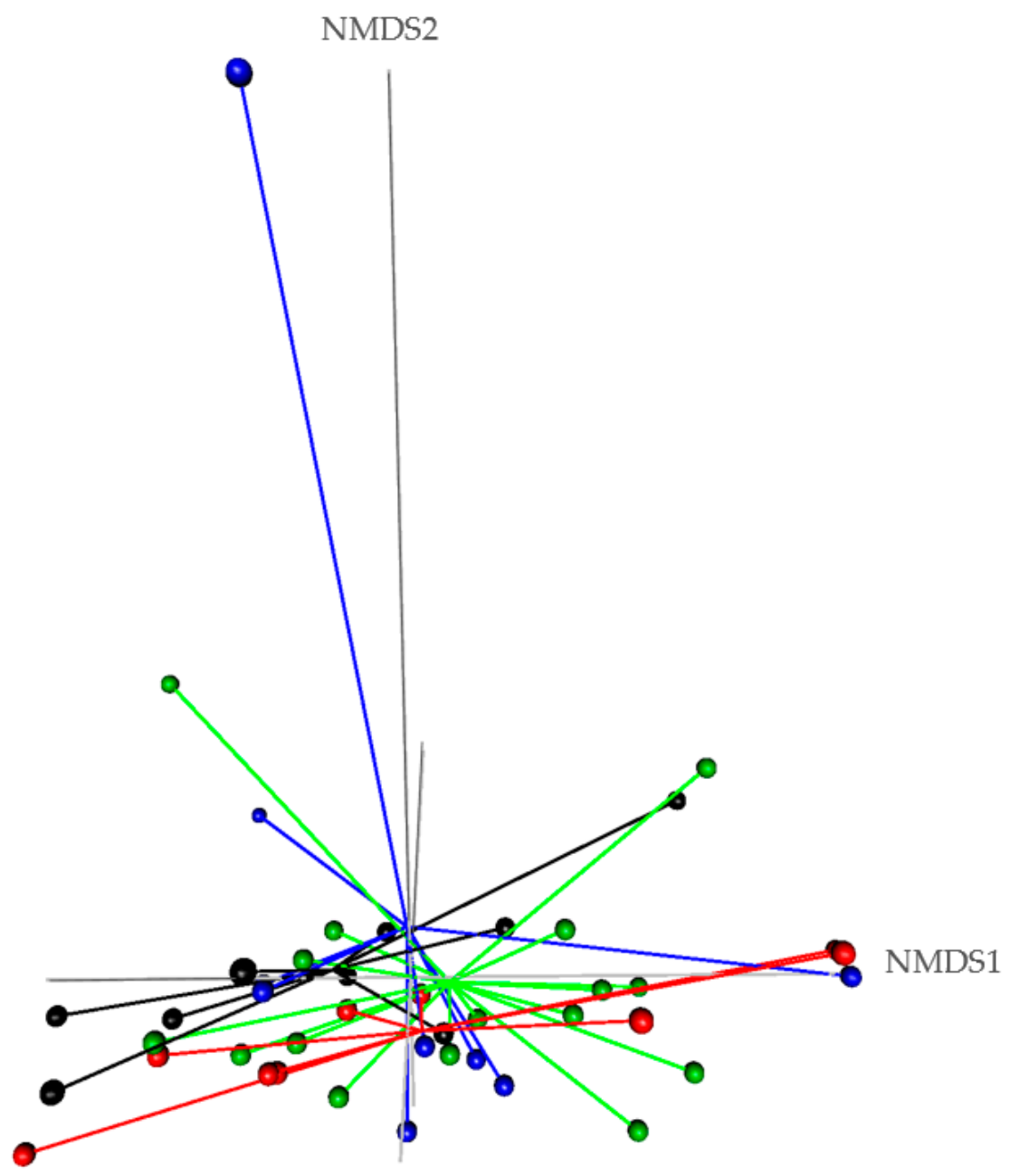

NMDS3

Figure 5. Comparison of beta diversity of rumen liquor bacterial community according to diet. Co: control; $\mathrm{T}_{\mathrm{oc}}: 35 \%$ olive cake; $\mathrm{T}_{\mathrm{cc}}: 30 \%$ cactus cladodes; $\mathrm{T}_{\mathrm{oc}+\mathrm{cc}}: 15 \%$ olive cake $+15 \%$ cactus cladodes) using nonmetric multidimensional scaling (NMDS) plots generated by Bray-Curtis distances. (• black dot: $\mathrm{Co} ; \bullet$ red dot: $\mathrm{T}_{\mathrm{oc}} ; \bullet$ green dot: $\mathrm{T}_{\mathrm{CC}} ; \bullet$ blue dot: $\left.\mathrm{T}_{\mathrm{oc}+\mathrm{cc}}\right)$.

Table 5. The effect of olive cake and cactus cladodes on fatty acid profile ( $\mathrm{g} / 100 \mathrm{~g}$ fat), groups $(\mathrm{g} / 100 \mathrm{~g}$ fat $)$, ratios, and indexes of goat kids meat.

\begin{tabular}{ccccccc}
\hline Item & Co & $\mathrm{T}_{\text {OC }}$ & $\mathrm{T}_{\mathbf{C C}}$ & $\mathrm{T}_{\text {OC+CC }}$ & SEM & $p$-Value \\
\hline $\mathrm{N}$ & 11 & 11 & 11 & 11 & & \\
$\mathrm{C} 4: 0$ & 0.308 & 0.457 & 0.370 & 0.452 & 0.039 & 0.651 \\
$\mathrm{C} 6: 0$ & $0.319^{\mathrm{ab}}$ & $0.443^{\mathrm{a}}$ & $0.207^{\mathrm{b}}$ & $0.235^{\mathrm{b}}$ & 0.026 & 0.011 \\
$\mathrm{C} 8: 0$ & 0.121 & $0.448^{2}$ & 0.379 & 0.330 & 0.044 & 0.102 \\
$\mathrm{C} 10: 0$ & 0.385 & 0.120 & 0.254 & 0.135 & 0.044 & 0.194 \\
$\mathrm{C} 11: 0$ & $0.246^{\mathrm{b}}$ & $0.692^{\mathrm{a}}$ & $0.222^{\mathrm{b}}$ & $0.426^{\mathrm{ab}}$ & 0.057 & 0.025 \\
$\mathrm{C} 12: 0$ & $0.831^{\mathrm{a}}$ & $0.193^{\mathrm{b}}$ & $0.220^{\mathrm{b}}$ & $0.216^{\mathrm{b}}$ & 0.078 & 0.033 \\
$\mathrm{C} 13: 0$ & 0.268 & 0.299 & 0.274 & 0.157 & 0.031 & 0.183 \\
$\mathrm{C} 14: 0$ & 0.984 & 1.11 & 0.967 & 1.25 & 0.056 & 0.234 \\
$\mathrm{C} 14: 1$ & 0.514 & 0.601 & 0.474 & 0.676 & 0.035 & 0.212 \\
$\mathrm{C} 15: 0$ & 6.81 & 5.85 & 5.62 & 5.29 & 0.377 & 0.804 \\
$\mathrm{C} 15: 1$ & 0.888 & 0.519 & 0.613 & 0.572 & 0.062 & 0.461 \\
\hline
\end{tabular}


Table 5. Cont.

\begin{tabular}{|c|c|c|c|c|c|c|}
\hline Item & Co & $\mathbf{T}_{\mathrm{OC}}$ & $\mathbf{T}_{\mathrm{CC}}$ & $\mathrm{T}_{\mathrm{OC}+\mathrm{CC}}$ & SEM & $p$-Value \\
\hline C16:0 & 12.5 & 12.2 & 14.7 & 13.5 & 0.507 & 0.112 \\
\hline C16:1 & 1.62 & 2.20 & 1.80 & 1.43 & 0.136 & 0.356 \\
\hline C17:0 & 3.30 & 4.54 & 4.11 & 4.08 & 0.272 & 0.609 \\
\hline C17:1 & 1.74 & 1.25 & 1.36 & 1.13 & 0.096 & 0.286 \\
\hline C18:0 & 14.9 & 18.4 & 17.8 & 18.3 & 0.799 & 0.454 \\
\hline 9t-C18:1 & 1.03 & 1.47 & 0.777 & 0.792 & 0.097 & 0.068 \\
\hline C18:1n-9 & 25.5 & 22.1 & 24.9 & 25.0 & 1.071 & 0.656 \\
\hline $6 \mathrm{t}-\mathrm{C} 18: 2$ & 0.497 & 0.443 & 0.418 & 0.275 & 0.039 & 0.270 \\
\hline C18:2n-6 & 6.12 & 5.15 & 4.76 & 6.14 & 0.238 & 0.184 \\
\hline C20:0 & 0.430 & 0.381 & 0.764 & 0.276 & 0.081 & 0.059 \\
\hline C18:3n-6 & 0.407 & 0.337 & 0.944 & 0.337 & 0.110 & 0.080 \\
\hline C20:1 & 0.375 & 0.383 & 1.03 & 0.449 & 0.149 & 0.305 \\
\hline C18:3n-3 & 0.489 & 0.687 & 0.546 & 0.620 & 0.054 & 0.668 \\
\hline C21:0 & $1.24^{\mathrm{ab}}$ & $1.93^{\mathrm{a}}$ & $0.501^{b}$ & $0.727^{b}$ & 0.162 & 0.007 \\
\hline C20:2 & 0.547 & 0.777 & 0.433 & 0.508 & 0.082 & 0.615 \\
\hline C22:0 & 1.90 & 1.24 & 1.36 & 1.54 & 0.092 & 0.267 \\
\hline C20:3n-6 & 0.503 & 0.606 & 0.436 & 0.764 & 0.052 & 0.202 \\
\hline C22:1n-9 & 0.362 & 0.364 & 0.662 & 0.522 & 0.077 & 0.485 \\
\hline$C 20: 3 n-3$ & 0.309 & 0.310 & 0.283 & 0.410 & 0.035 & 0.520 \\
\hline C20:4n-6 & 1.02 & 0.526 & 1.05 & 0.593 & 0.114 & 0.253 \\
\hline C23:0 & 4.89 & 6.16 & 5.68 & 5.35 & 0.248 & 0.306 \\
\hline C22:2 & $0.401^{\mathrm{c}}$ & $1.05^{\mathrm{a}}$ & $0.410^{b c}$ & $0.969^{a b}$ & 0.089 & 0.015 \\
\hline C24:0 & 1.18 & 1.82 & 1.17 & 1.12 & 0.141 & 0.350 \\
\hline C20:5n-3 & 0.734 & 1.36 & 1.15 & 1.40 & 0.128 & 0.385 \\
\hline C24:1 & $3.57^{\mathrm{a}}$ & $1.26^{b}$ & $1.56^{\mathrm{b}}$ & $1.36^{\mathrm{b}}$ & 0.205 & 0.002 \\
\hline$C 22: 6 n-3$ & 2.86 & 2.25 & 1.80 & 2.65 & 0.144 & 0.071 \\
\hline \multicolumn{7}{|l|}{ Summary } \\
\hline SCFA & 1.13 & 1.47 & 1.21 & 1.15 & 0.089 & 0.424 \\
\hline MCFA & 2.84 & 2.90 & 2.16 & 2.73 & 0.330 & 0.560 \\
\hline LCFA & 96.0 & 95.6 & 96.6 & 96.1 & 0.376 & 0.451 \\
\hline SFA & 50.6 & 56.4 & 54.6 & 53.5 & 0.883 & 0.195 \\
\hline MUFA & 35.2 & 29.8 & 32.5 & 31.4 & 0.866 & 0.520 \\
\hline PUFA & 13.9 & 13.5 & 12.2 & 14.7 & 0.650 & 0.087 \\
\hline DFA & 64.0 & 61.7 & 62.5 & 64.4 & 0.755 & 0.733 \\
\hline$n-3$ & 4.39 & 4.61 & 3.78 & 5.08 & 0.237 & 0.059 \\
\hline$n-6$ & 8.55 & 7.07 & 7.61 & 8.11 & 0.344 & 0.409 \\
\hline$n-9$ & 26.9 & 23.9 & 26.3 & 26.3 & 0.943 & 0.244 \\
\hline \multicolumn{7}{|l|}{ Ratio } \\
\hline UFA/SFA & 0.971 & 0.768 & 0.819 & 0.861 & 0.035 & 0.207 \\
\hline$n-6 / n-3$ & 1.94 & 1.53 & 2.01 & 1.60 & 0.134 & 0.421 \\
\hline PUFA/SFA & 0.275 & 0.240 & 0.224 & 0.274 & 0.019 & 0.303 \\
\hline MUFA/PUFA & 2.54 & 2.20 & 2.66 & 2.14 & 0.312 & 0.513 \\
\hline \multicolumn{7}{|l|}{ Index } \\
\hline AI & 0.351 & 0.390 & 0.420 & 0.408 & 0.014 & 0.420 \\
\hline $\mathrm{TI}$ & 0.796 & 0.966 & 1.05 & 0.931 & 0.060 & 0.619 \\
\hline$(\mathrm{C} 18: 0+\mathrm{C} 18: 1) / \mathrm{C} 16: 0$ & 3.32 & 3.43 & 2.95 & 3.26 & 0.086 & 0.058 \\
\hline$\Delta 9 \mathrm{C} 14$ & 0.343 & 0.350 & 0.329 & 0.351 & 0.016 & 0.922 \\
\hline$\Delta 9 \mathrm{C} 16$ & 0.115 & 0.152 & 0.109 & 0.095 & 0.013 & 0.148 \\
\hline$\Delta 9 \mathrm{C} 18$ & 0.641 & 0.561 & 0.591 & 0.584 & 0.013 & 0.599 \\
\hline
\end{tabular}

Co: control diet; $\mathrm{T}_{\mathrm{OC}}$ : diet with $35 \%$ of olive cake; $\mathrm{T}_{\mathrm{CC}}$ : diet with $30 \%$ of cactus cladodes; $\mathrm{T}_{\mathrm{OC}+\mathrm{CC}}$ : diet with $15 \%$ of olive cake and $15 \%$ of cactus cladodes; AI: atherogenicity index; TI: thrombogenic index; DFA: desirable fatty acids; MUFA: monounsaturated fatty acids; PUFA: polyunsaturated fatty acids; SFA: saturated fatty acids ; SEM: standard error of mean; ${ }^{\mathrm{a}, \mathrm{b}, \mathrm{c}}$ : values followed by different letters are significantly different at $p<0.05$.

\section{Discussion}

The rumen has the capacity to valorize resources that are inedible for humans (forage, concentrate, by-products, etc.) to transform them into a final edible product (milk and meat), especially in areas with a harsh environment [3]. This ability is due to its microbial 
ecosystem richness that living in symbiosis with the ruminants, which has the capacity to degrade fibers (cellulose and hemicellulose) to volatile fatty acids (acetate, butyrate, and propionate) as final metabolism products [3].

Rumen liquor $\mathrm{pH}$ depends on volatile fatty acids (VFA) production that is variable according to distributed diet and bacterial composition. Ruminal $\mathrm{pH}$ is related mainly to carbohydrates, fibers, and protein content of diet [46]. The $\mathrm{pH}$ of the control and 35\% OC rumen liquor was lower than the average $\mathrm{pH}$ of goat close to 6.2 , which presents a latent acidosis in these groups [46]. The $\mathrm{pH}$ of the control diet was more acid than the test groups because of its high content on barley that has a high acidogenic capacity compared to the other concentrates [47] due to its high content on carbohydrates. The incorporation of CC did not reduce the $\mathrm{pH}$ despite its high content in soluble carbohydrates that could disturb rumen fermentation conditions and induce, thereby, acidosis. The CC $\mathrm{pH}$ could not have been affected because CC mucilage stimulated salivation and allowed higher rumen fermentation stability [25].

The digestibility of ingested feed by ruminants depends mainly on their composition and the microbiota present in the digestive tract. The microbiota from the rumen liquor of test groups was able to digest the control diet constituents in the same efficiency as the control groups' liquor. This similarity could be due to the control diet constituent that is present in the test groups' diet. However, the control rumen liquor was less adapted to digest the test diets because they contained probably ingredients, which flora was not accustomed to.

The bacterial community of rumen liquor that provides nutrients to the host by the metabolic activities [3] is a complex system characterized by rapid changes with diet composition affecting ruminal $\mathrm{pH}$ and fermentation products $[14,48]$. A low $\mathrm{pH}$ value is a result of the high lactic acid production to the detriment of VFA because of the substitution of cellulolytic by lactic acid producers' flora [46]. Many studies aimed to improve the ruminants' products (meat and milk) quality, especially their lipid and fatty acids content, by changing diet composition [13-16]. The distributed diets could improve product quality by increasing PUFA due to perturbation of the ruminal ecosystem and implicitly of FA biohydrogenation. These diets are characterized by a high content of desirable fatty acids and/or antimicrobial activity such as polyphenols, oxalic acid, essential oils [14].

The rumen liquor of goat kids was characterized by the same diversity, richness, and evenness within groups at genera and species levels. In disagreement with the current results, Wang et al. [49] reported 1708 and 1641 for Chao1, 1557 and 1508 for observed species, and 0.98 for Simpson index in goat rumen, respectively with low and high nitrogen use, and Liu et al. [50] found a range of 1290-1746 OTU, 559-988 Chao1 and 0.94-0.98 Simpson index in juvenile goat rumen liquor. The main phyla in goat kids' liquor were Bacteroidetes, Firmicutes, and Proteobacteria with an average of $46.4 \%, 33.4 \%$, and $12.7 \%$, respectively, and a total of both Bacteroidetes and Firmicutes of 79.8\% of total phyla. Mannelli et al. [14] reported in the microbiota dairy ewes supplemented with OC Bacteroidetes and Firmicutes domination with $56 \%$ and $32 \%$, respectively, and with a total of $89 \%$ for both that is higher than the current result. This difference could be explained by the low importance of Bacteroidetes in the current finding and the species compared to the literature. The current finding remained in the range reported by Liu et al. [50] for Bacteroidetes $(33.6 \%-52.8 \%)$, Firmicutes (18.1\%-35.3\%), and Proteobacteria (3.29\%-20.0\%) of juvenile goat rumen. Overall, Firmicutes, Bacteroidetes, and Proteobacteria are the main phyla in rumen liquor of all ruminant species $[48,51]$. Many authors reported the positive correlation of Firmicutes/Bacteriodetes ratio with obesity for humans and animals $[52,53]$ because of its role in adipogenesis $[54,55]$. This ratio was similar in all groups of rumen liquor even it was variable from 1.26 to 7.29. The inclusion of OC in goat kids' diet did not affect alpha and beta diversity of rumen liquor comparatively to the finding of Mannelli et al. [14] with 2 and 3 phases OC, and of Cappucci et al. [56] with OC phenolic concentrate, and Mateos et al. [31] for dairy ewes. In addition, the CC incorporation did not alter rumen liquor diversity. The CC contains oxalate that is suspected of having an antimicrobial effect [10]. 
Belenguer et al. [57] reported a lack of oxalic acid effect on alpha diversity of rumen liquor of ewes. The similarity in all groups' diversity could be due to their similar fiber content because the bacterial diversity is positively correlated to the fiber content $[48,58]$.

The OTU was not mainly influenced by the diets. An effective of three taxas were affected by difference to results of Mannelli et al. [14], Pallara et al. [16], Mateos et al. [31] with OC inclusion in dairy ewes' diet. This difference compared to literature could be explained by the studied species, the extraction method of used OC, the tested rumen liquor, and the essay duration. Goat species is known, compared to other ruminants, by its ability to valorize feeds with low protein and high lignin and tannins due to its microbiota specificity [15,22,32,33]. Mannelli et al. [14] reported some differences of 2 and 3 phases centrifugation OC effect on dairy ewes' microbial community. This difference could be due to their variable content on residual oil and polyphenols [20]. In addition, fermentations reported in the literature were performed in vitro for 14 to 28 days using RUSITEC (rumen simulation technique) with rumen liquor of live animals [14,16,31]. At the families' level, Defluviitaleaceae was significantly higher with 30\% CC. Lin et al. [59] reported that Defluviitaleaceae is correlated negatively to obesity that explains the low fat in lean meat of semimembranosus of animals fed on CC found by several authors [9,21]. Fusobacteriaceae tended to be higher in the group receiving both of the resources. The Fusobacteriaceae family contained in goat kids' rumen liquor one genus (Fusobacterium) that includes pathogen bacteria and butyric acid producers [60,61], which could explain the projection outside of the sample of this group in the NMDS plot. In the Fusobacterium genus, two species were observed in goat kids' rumen liquor, which were Fusobacterium_16S_OTU89845 and Fusobacterium_JF975740. The NED5E9 fa belongs to the Tenericutes phylum, which is increased by CC incorporation. However, this family is not well known and not well described in the literature. At the genera level, rumen liquor of the conventional diet contained significantly more Aeriscardovia than all test groups because the control group had a diet with barley, and this genus uses starch [62] to produce lactic acid [63], which explain the low ruminal $\mathrm{pH}$ of this group. In the Lachnospiraceae family, Lachnospiraceae_NK4B4_group was higher in $35 \%$ OC liquor. Combes et al. [64] found an increase in Lachnospiraceae_NK4B4_group with a low-protein diet before weaning in rabbits, and the protein of 35\% OC diet was slightly lower than control. In addition, these results could be explained by the high content of OC with fibers that are necessary to cellulolytic bacteria growth [14]. Butyrivibrio_2 is a butyrate producer genus found in rich fibers environment able to degrade structural carbohydrates, mainly hemicelluloses and xylan [65], to break down protein, and to biohydrogenate lipid by conversion linoleic to stearic acid $[14,16,54]$. The $35 \%$ OC incorporation tendency to enrich rumen liquor in Butyrivibrio_2 could be an adaptation to degrade fibers that were slightly higher in the diet compared to control and to biohydrogenate the PUFA contained in OC. Marvinbryantia tended to be higher with 30\% CC that could be one of the responsible factors of the lean meat of animals receiving CC because this genus is related negatively to weight and provide acetic acid from cellulose and methylcellulose degradation [66]. The goat kids' rumen liquor with the conventional diet tended to produce more acetic acid, and this could be linked to the content of the Howardella genus that is an acetate producer [67]. The Atopobiaceae genus tended to extend with test diets inclusion. The family of this genus is known for the ability to produce lactic, acetic, and formic acids as a final product of glucose metabolism [68]. In the Veillonellaceae family, 35\% OC rumen liquor did not affect Anaerovibrio content that is a lypolytic genus [69] contrarily to Mannelli et al. [14], who reported a decrease in Anaerovibrio genus in dairy ewes' rumen with OC incorporation that is affecting PUFA biohydragenation [15]. This difference could be explained by the kind of used OC, the species and the sex of animals, and the experiment duration [14-16,20,22,31-33]. In addition, this difference compared to Mannelli et al. [14] could be caused by the diet composition that contains less concentrate for dairy animals in comparison to growing fattening animals' diets because the high content of concentrate promotes Anaerovibrio growth [70]. The effect of OC on the Anaerovibrio genus in dairy ewes' rumen liquor could be due to the tannins content that is toxic for fibrolytic bacte- 
ria [71] and the antimicrobial effect of olive oil [72,73]. Compared to sheep, goats exposed to tanniniferous feed have the ability to produce more saliva quantity and proline-rich salivary proteins that are capable of deactivating condensed tannins activity, which might explain the lack of tannins effect from OC on Anaerovibrio genus [74,75]. Thereby, goat kids could be adapted to degrade the high contents of condensed tannins and ether extract of OC. In the same family, the CC administration tended to impoverish the rumen liquor with Selenomonas_1, a propionate producer genus [76]. The low propionate production allows lowering fat deposit, which could be the cause of the lean semimembranosus of goat kids fed on CC [77]. The Ruminococcaceae_UCG-001 belongs to the Ruminococcaceae family that is known for fibers digestibility and acetate production [78,79]. This genus tended to be higher with $35 \%$ OC because of the high content of this diet with fibers.

The inclusion of the studied alternative feed resources had a moderate effect on the fatty acid profile. This moderate variation could be a result of the similarity of microbiota diversity and the slight effect of diet on genus microbiota relative abundance. The increase in C11:0 by OC administration in $\mathrm{T}_{\mathrm{OC}}$ could be explained by the presence of the residual olive oil in this by-product because Lerma-Reyes et al. [80] found an increase in C11:0 in goat milk following canola or soybean oil incorporation. The C12:0 that is considered as hypercholesterolemic fatty acid [11] decreased positively in goat meat with the studied resources administration. This reduction could be related to the C12:0 content in the diet [22]. Vera et al. [81] and Kotsampasi et al. [22] reported a C12:0 reduction in subcutaneous and intramuscular fat of lambs with OC inclusion, in agreement with the current result. The incorporation in $\mathrm{T}_{\mathrm{OC}}$ and $\mathrm{T}_{\mathrm{oc}+\mathrm{cc}}$ groups of OC increased the C22:2 in intramuscular fat of chevon, as a result of elongation of C18:3n-3 and C18:3n- 6 by elongase in association with $\Delta 5$ and $\Delta 6$ desaturase enzymes [82]. The $9 \mathrm{t}-\mathrm{C} 18: 1$ is an intermediate product of UFA biohydrogenation before being converted to stearic acid (C18:0). The trend for a higher concentration of 9t-C18:1 in $\mathrm{T}_{\mathrm{oc}}$ meat could be due to the high content of OC in UFA and the trend for the high relative abundance of Butyrivibrio in $\mathrm{T}_{\mathrm{oc}}$ rumen liquor, the bacteria the most involved in the biohydrogenation process.

\section{Conclusions}

The incorporation of olive cake and cactus cladodes in goat kids' diet did not strongly change the bacterial composition of rumen liquor and meat quality. Microbiota from goat kids seems to be able to adapt to digest the alternatives feed resources. The composition of these resources and the final products of metabolism are responsible for the meat quality changes. Thus, olive cake and cactus cladodes are two alternatives feed resources without negative effect on microbiota compared to a conventional feed. They could take place in goat kids' diet with a need for nitrogen enrichment because of their low proteins content. The inclusion of these feedstuffs could diversify the goat diet and reduce feed cost, and also their dependence only on the forest rangelands. The adaptation of goat ruminal microbiota could encourage the exploitation of inedible resources for humans and incorporate them in ruminants' diet to provide edible foods. Further studies are recommended to evaluate the effect of these resources and other unconventional feedstuffs on the microbiota of dairy goats.

Author Contributions: Conceptualization, S.E.O.; methodology, S.E.O., M.C., J.-L.H. and J.-F.C.; laboratory analysis, S.E.O. and B.T.; formal analysis, S.E.O., Y.C., M.C., J.-L.H. and J.-F.C.; data curation, S.E.O. and B.T.; writing—original draft preparation, S.E.O., Y.C. and B.T.; writing-review and editing, Y.C., M.C., J.-L.H., J.-F.C. and B.T.; project administration, S.E.O. and J.-F.C.; funding acquisition, S.E.O. All authors have read and agreed to the published version of the manuscript.

Funding: This project received funding from the Academy for Research and Higher EducationDevelopment Cooperation Committee (ARES-CCD), Brussels, Belgium. This study is realized in the framework of the Research Project for Development: PRD (2013-2018). 
Institutional Review Board Statement: All study procedures and Guidelines for Experimental Animals were approved by the Regional Center of Agricultural Research of Tangier (number: 01/CRRAT/2017).

Informed Consent Statement: Not applicable.

Data Availability Statement: The data presented in this study are available within the article.

Acknowledgments: The authors would like to thank the Research for Development Project and INRA collaborators.

Conflicts of Interest: The authors declare no competing financial interest.

\section{References}

1. Chebli, Y.; Chentouf, M.; Ozer, P.; Hornick, J.L.; Cabaraux, J.F. Forest and silvopastoral cover changes and its drivers in northern Morocco. Appl. Geogr. 2018, 101, 23-35. [CrossRef]

2. Webb, E.C.; Casey, N.H.; Simela, L. Goat meat quality. Small Rumin. Res. 2005, 60, 153-166. [CrossRef]

3. Wallace, J.R.; Sasson, G.; Garnsworthy, P.C.; Tapio, I.; Gregson, E.; Bani, P.; Huhtanen, P.; Bayat, A.R.; Strozzi, F.; Biscarini, F.; et al. A heritable subset of the core rumen microbiome dictates dairy cow productivity and emissions. Sci. Adv. 2019, 5, eaav8391. [CrossRef]

4. Chebli, Y.; El Otmani, S.; Chentouf, M.; Hornick, J.L.; Cabaraux, J.F. Temporal variations in chemical composition, in vitro digestibility, and metabolizable energy of plant species browsed by goats in Southern Mediterranean forest rangeland. Animals 2021, 11, 1441. [CrossRef] [PubMed]

5. Chebli, Y.; El Otmani, S.; Elame, F.; Moula, N.; Chentouf, M.; Hornick, J.L.; Cabaraux, J.F. Silvopastoral system in Morocco: Focus on their importance, strategic functions, and recent changes in the Mediterranean side. Sustainability 2021, 13, 10744. [CrossRef]

6. Vasta, V.; Luciano, G. The effects of dietary consumption of plants secondary compounds on small ruminants' products quality. Small Rumin. Res. 2011, 101, 150-159. [CrossRef]

7. Mele, M.; Serra, A.; Pauselli, M.; Luciano, G.; Lanza, M.; Pennisi, P.; Conte, G.; Taticchi, A.; Esposto, S.; Morbidini, L. The use of stoned olive cake and rolled linseed in the diet of intensively reared lambs: Effect on the intramuscular fatty-acid composition. Animal 2014, 8, 152-162. [CrossRef] [PubMed]

8. El Otmani, S.; Chebli, Y.; Chentouf, M.; Hornick, J.L.; Cabaraux, J.F. Effects of olive cake and cactus cladodes as alternative feed resources on goat milk production and quality. Agriculture 2021, 11, 3. [CrossRef]

9. El Otmani, S.; Chebli, Y.; Hornick, J.L.; Cabaraux, J.F.; Chentouf, M. Growth performance, carcass characteristics and meat quality of male goat kids supplemented by alternative feed resources: Olive cake and cactus cladodes. Anim. Feed Sci. Technol. 2021, 272, 114746. [CrossRef]

10. Chentli, A.; Gillmann, L.; Bouazza, L.; Medjkal, S.; Limami, A.M.; Le Paven, M.C.M.; Bousseboua, H. Effects of secondary compounds from cactus and acacias trees on rumen microbial profile changes performed by Real-Time PCR. Int. J. Adv. Res. 2014, 2, 660-671.

11. Banskalieva, V.; Sahlu, T.; Goetsch, A.L. Fatty acid composition of goat muscles and fat depots: A review. Small Rumin. Res. 2000, 37, 255-268. [CrossRef]

12. Infascelli, L.; Tudisco, R.; Iommelli, P.; Capitanio, F. Milk Quality and animal welfare as a possible marketing lever for the economic development of rural areas in Southern Italy. Animals 2021, 11, 1059. [CrossRef]

13. Luciano, G.; Pauselli, M.; Servili, M.; Mourvaki, E.; Serra, A.; Monahan, F.J.; Lanza, M.; Priolo, A.; Zinnai, A.; Mele, M. Dietary olive cake reduces the oxidation of lipids, including cholesterol, in lamb meat enriched in polyunsaturated fatty acids. Meat Sci. 2013, 93, 703-714. [CrossRef]

14. Mannelli, F.; Cappucci, A.; Pini, F.; Pastorelli, R.; Decorosi, F.; Giovannetti, L.; Mele, M.; Minieri, S.; Conte, G.; Pauselli, M.; et al. Effect of different types of olive oil pomace dietary supplementation on the rumen microbial community profile in Comisana ewes. Sci. Rep. 2018, 8, 1-11. [CrossRef]

15. Molina-Alcaide, E.; Yáñez-Ruiz, D.R. Potential use of olive by-products in ruminant feeding: A review. Anim. Feed Sci. Technol. 2008, 147, 247-264. [CrossRef]

16. Pallara, G.; Buccioni, A.; Pastorelli, R.; Minieri, S.; Mele, M.; Rapaccini, S.; Messini, A.; Pauselli, M.; Servili, M.; Giovannetti, L.; et al. Effect of stoned olive pomace on rumen microbial communities and polyunsaturated fatty acid biohydrogenation: An in vitro study. BMC Vet. Res. 2014, 10, 271. [CrossRef]

17. Tudisco, R.; Chiofalo, B.; Addi, L.; Lo Presti, V.; Rao, R.; Calabrò, S.; Musco, N.; Grossi, M.; Cutrignelli, M.I.; Mastellone, V.; et al. Effect of hydrogenated palm oil dietary supplementation on milk yield and composition, fatty acids profile and Stearoyl-CoA desaturase expression in goat milk. Small Rumin. Res. 2015, 132, 72-78. [CrossRef]

18. Vasta, V.; Nudda, A.; Cannas, A.; Lanza, M.; Priolo, A. Alternative feed resources and their effects on the quality of meat and milk from small ruminants. Anim. Feed Sci. Technol. 2008, 147, 223-246. [CrossRef]

19. Arco-Pérez, A.; Ramos-Morales, E.; Yáñez-Ruiz, D.R.; Abecia, L.; Martín-García, A.I. Nutritive evaluation and milk quality of including of tomato or olive by-products silages with sunflower oil in the diet of dairy goats. Anim. Feed Sci. Technol. 2017, 232, 57-70. [CrossRef] 
20. El Otmani, S.; Chentouf, M.; Hornick, J.L.; Cabaraux, J.F. Chemical composition and in vitro digestibility of alternative feed resources for ruminants in Mediterranean climates: Olive cake and cactus cladodes. J. Agric. Sci. 2019, 157, 260-271. [CrossRef]

21. Mahouachi, M.; Atti, N.; Hajji, H. Use of spineless cactus (Opuntia ficus indica f. inermis) for dairy goats and growing kids: Impacts on milk production, kid's growth, and meat quality. Sci. World J. 2012, 2012, 321567. [CrossRef]

22. Kotsampasi, B.; Bampidis, V.A.; Tsiaousi, A.; Christodoulou, C.; Petrotos, K.; Amvrosiadis, I.; Fragioudakis, N.; Christodoulou, V. Effects of dietary partly destoned exhausted olive cake supplementation on performance, carcass characteristics and meat quality of growing lambs. Small Rumin. Res. 2017, 156, 33-41. [CrossRef]

23. Atti, N.; Maamouri, O.; Hajji, H.; Mahouachi, M. Utilisation du cactus inerme comme aliment de base pour la chèvre en lactation: Impacts sur la production laitière et la croissance des chevreaux. Livest. Res. Rural Dev. 2010, $22,7$.

24. Atti, N.; Mahouachi, M.; Rouissi, H. The effect of spineless cactus (Opuntia ficus-indica f. inermis) supplementation on growth, carcass, meat quality and fatty acid composition of male goat kids. Meat Sci. 2006, 73, 229-235. [CrossRef] [PubMed]

25. Abidi, S.; Ben Salem, H.; Vasta, V.; Priolo, A. Supplementation with barley or spineless cactus (Opuntia ficus indica f. inermis) cladodes on digestion, growth and intramuscular fatty acid composition in sheep and goats receiving oaten hay. Small Rumin. Res. 2009, 87, 9-16. [CrossRef]

26. Chiofalo, B.; Liotta, L.; Zumbo, A.; Chiofalo, V. Administration of olive cake for ewe feeding: Effect on milk yield and composition. Small Rumin. Res. 2004, 55, 169-176. [CrossRef]

27. Terramoccia, S.; Bartocci, S.; Taticchi, A.; Di Giovanni, S.; Pauselli, M. Use of dried stoned olive pomace in the feeding of lactating buffaloes: Effect on the quantity and quality of the milk produced. Asian Australas. J. Anim. Sci. 2013, 26, 971-980. [CrossRef]

28. Vargas-Bello-Pérez, E.; Vera, R.R.; Aguilar, C.; Lira, R.; Peña, I.; Fernández, J. Feeding olive cake to ewes improves fatty acid profile of milk and cheese. Anim. Feed Sci. Technol. 2013, 184, 94-99. [CrossRef]

29. Dusart, C. La Digestion Ruminale: Mise en Place d'un Modèle d'étude In Vitro à Long Terme en Cultures Batch. Ph.D. Thesis, Toulouse University, Toulouse, France, 2014.

30. Jones, G.A.; McAllister, T.A.; Cheng, K.J.; Muir, A.D. Effect of sainfoin (Onobrychris viciifolia Scop.) condensed tannins on growth and proteolysis by 4 strains of rumen bacteria. Appl. Environ. Microbiol. 1994, 60, 1374-1378. [CrossRef]

31. Mateos, I.; Saro, C.; Carro, M.D.; Ranilla, M.J. Using by-Products in Dairy Sheep Diets: Effects on Ruminal Bacterial Communities In XVIII Jornadas Sobre Producción Animal, Zaragoza, Spain, 7 and 8 May 2019; Asociación Interprofesional para el Desarrollo Agrario: Zaragoza, Spain, 2019. Available online: http://www.aida-itea.org/aida-itea/files/jornadas/2019/Comunicaciones/20 19_NyA_60.pdf (accessed on 10 September 2020).

32. Belenguer, Á.; Frutos, P.; Bernard, L.; Hervás, G.; Chilliard, Y.; Toral, P.G. Comparación de la fermentación y la comunidad bacteriana del rumen en vacas y cabras alimentadas con la misma dieta. In Proceedings of the AIDA (2013) XV Jornadas Sobre Producción Animal, Zaragoza, Spain, 14-15 May 2013; Asociación Interprofesional para el Desarrollo Agrario: Zaragoza, Spain, 2013; Tomo II, pp. 860-862.

33. Brooker, J.D.; O’Donovan, L.A.; Skene, I.; Clarke, K.; Blackall, L.; Muslera, P. Streptococcus caprinus sp. Nov., a tannin-resistant ruminal bacterium from feral goats. Lett. Appl. Microbiol. 1994, 18, 313-318. [CrossRef]

34. Hilal, B.; El Otmani, S.; Chentouf, M.; Boujenane, L. Morphological characterization of the local goat population "Beni Arrous". Options Méditerranéennes 2014, 437, 433-437.

35. El Otmani, S.; Hilal, B.; Chentouf, M. Milk production and composition of 'Beni Arousse' North Moroccan local goat. Options Méditerranéennes 2013, 108, 457-461.

36. Palmieri, A.D.; de Carvalho, G.G.P.; Tosto, M.S.L.; Leite, V.M.; Santos, S.A.; Borja, M.S.; Azevêdo, J.A.G.; Júnior, J.E.d.F.; Leite, L.C.; Ayres, M.C.C.; et al. Nutritional and productive performance of goats kids fed diets with detoxified castor meal. Anim. Feed Sci. Technol. 2016, 216, 81-92. [CrossRef]

37. Mabjeesh, S.J.; Cohen, M.; Arieli, A. In vitro methods for measuring the dry matter digestibility of ruminant feedstuffs: Comparison of methods and inoculum source. J. Dairy Sci. 2000, 83, 2289-2294. [CrossRef]

38. Yu, Z.; Morrison, M. Improved extraction of PCR-quality community DNA from digesta and fecal samples. Biotechniques 2004, 36, 808-812. [CrossRef] [PubMed]

39. Schloss, P.D.; Westcott, S.L.; Ryabin, T.; Hall, J.R.; Hartmann, M.; Hollister, E.B.; Lesniewski, R.A.; Oakley, B.B.; Parks, D.H.; Robinson, C.J.; et al. Introducing mothur: Open-source, platform-independent, community-supported software for describing and comparing microbial communities. Appl. Environ. Microbiol. 2009, 75, 7537-7541. [CrossRef] [PubMed]

40. Neyrinck, A.M.; Etxeberria, U.; Taminiau, B.; Daube, G.; Van Hul, M.; Everard, A.; Cani, P.D.; Bindels, L.B.; Delzenne, N.M Rhubarb extract prevents hepatic inflammation induced by acute alcohol intake, an effect related to the modulation of the gut microbiota. Mol. Nutr. Food Res. 2016, 61, 1500899. [CrossRef] [PubMed]

41. Rognes, T.; Flouri, T.; Nichols, B.; Quince, C.; Mahé, F. VSEARCH: A versatile open-source tool for metagenomics. PeerJ 2016, 4, e2584. [CrossRef] [PubMed]

42. Quast, C.; Pruesse, E.; Yilmaz, P.; Gerken, J.; Schweer, T.; Yarza, P.; Peplies, J.; Glockner, F.O. The silva ribosomal RNA gene database project: Improved data processing and web-based tools. Nucleic Acids Res. 2013, 41, D590-D596. [CrossRef]

43. Mioč, B.; Pavić, V.; Vnučec, I.; Prpić, Z.; Kostelić, A.; Sušić, V. Effect of olive cake on daily gain, carcass characteristics and chemical composition of lamb meat. Czech J. Anim. Sci. 2007, 52, 31-36. [CrossRef]

44. Folch, J.; Lees, M.; Stanley, G.H.S. A simple method for the isolation and purification of total lipids from animal tissues. J. Biol. Chem. 1957, 226, 497-509. [CrossRef] 
45. AOAC. Official Methods of Analysis of AOAC International. Fatty Acids in Oils and Fats, Preparation of Methyl Esters Boron Trifluoride Method, 15th ed.; AOAC Official Method 969.33; AOAC International: Washington, DC, USA, 1990.

46. Sauvant, D.; Meschy, F.; Mertens, D. Les composantes de l'acidose ruminale et les effets acidogènes des rations. Prod. Anim. 1999, 12, 49-60. [CrossRef]

47. Giger-Reverdin, S.; Sauvant, D. Meta-analysis of the acidogenicity of ingredients. J. Anim. Sci. 2001,79 (Suppl. 1), 79.

48. Iqbal, M.W.; Zhang, Q.; Yang, Y.; Zou, C.; Li, L.; Liang, X.; Wei, S.; Lin, B. Ruminal fermentation and microbial community differently influenced by four typical subtropical forages in vitro. Anim. Nutr. 2018, 4, 100-108. [CrossRef] [PubMed]

49. Wang, L.; Liu, K.; Wang, Z.; Bai, X.; Peng, Q.; Jin, L. Bacterial community diversity associated with different utilization efficiencies of nitrogen in the gastrointestinal tract of goats. Front. Microbiol. 2019, 10, 1-14. [CrossRef] [PubMed]

50. Liu, Q.; Yao, S.; Chen, Y.; Gao, S.; Yang, Y.; Deng, J.; Ren, Z.; Shen, L.; Cui, H.; Hu, Y.; et al. Use of antimicrobial peptides as a feed additive for juvenile goats. Sci. Rep. 2017, 7, 1-11. [CrossRef] [PubMed]

51. Henderson, G.; Cox, F.; Ganesh, S.; Jonker, A.; Young, W.; Global Rumen Census Collaborators; Janssen, P.H. Rumen microbial community composition varies with diet and host, but a core microbiome is found across a wide geographical range. Sci. Rep. 2015, 5, 14567. [CrossRef]

52. Bajzer, M.; Seeley, R.J. Physiology: Obesity and gut flora. Nature 2006, 444, 1009-1010. [CrossRef] [PubMed]

53. Ley, R.E.; Turnbaugh, P.; Klein, S.; Gordon, J.I. Microbial ecology: Human gut microbes associated with obesity. Nature 2006, 444, 1022-1023. [CrossRef] [PubMed]

54. He, Y.; Wang, H.; Yu, Z.; Niu, W.; Qiu, Q.; Su, H.; Cao, B. Effects of the gender differences in cattle rumen fermentation on anaerobic fermentation of wheat straw. J. Clean. Prod. 2018, 205, 845-853. [CrossRef]

55. Biscarini, F.; Palazzo, F.; Castellani, F.; Masetti, G.; Grotta, L.; Cichelli, A.; Martino, G. Rumen microbiome in dairy calves fed copper and grape-pomace dietary supplementations: Composition and predicted functional profile. PLoS ONE 2018, 13, e0205670. [CrossRef]

56. Cappucci, A.; Alves, S.P.; Bessa, R.J.B.; Buccioni, A.; Mannelli, F.; Pauselli, M.; Viti, C.; Pastorelli, R.; Roscini, V.; Serra, A.; et al. Effect of increasing amounts of olive crude phenolic concentrate in the diet of dairy ewes on rumen liquor and milk fatty acid composition. J. Dairy Sci. 2018, 101, 4992-5005. [CrossRef]

57. Belenguer, A.; Ben Bati, M.; Hervás, G.; Toral, P.G.; Yáñez-Ruiz, D.R.; Frutos, P. Impact of oxalic acid on rumen function and bacterial community in sheep. Animal 2013, 7, 940-947. [CrossRef] [PubMed]

58. Grilli, D.J.; Fliegerova, K.; Kopecný, J.; Lama, S.P.; Egea, V.; Sohaefer, N.; Pereyra, C.; Soledad Ruiz, M.; Sosa, M.A.; Arenas, G.N.; et al. Analysis of the rumen bacterial diversity of goats during shift from forage to concentrate diet. Anaerobe 2016, 42, 17-26. [CrossRef]

59. Lin, H.; An, Y.; Hao, F.; Wang, Y.; Tang, H. Correlations of fecal metabonomic and microbiomic changes induced by high-fat diet in the pre-obesity state. Sci. Rep. 2016, 6, 1-14. [CrossRef]

60. Nagaraja, T.G.; Narayanan, S.K.; Stewart, G.C.; Chengappa, M.M. Fusobacterium necrophorum infections in animals: Pathogenesis and pathogenic mechanisms. Anaerobe 2005, 11, 239-246. [CrossRef] [PubMed]

61. Rosenberg, E.; DeLong, E.F.; Lory, S.; Stackebrandt, E.; Thompson, F. The Prokaryotes: Gammaproteobacteria, 4th ed.; Springer: Berlin/Heidelberg, Germany, 2013; pp. 1-768. [CrossRef]

62. Killer, J.; Kopečný, J.; Mrázek, J.; Havlík, J.; Koppová, I.; Benada, O.; Rada, V.; Kofroňová, O. Bombiscardovia coagulans gen. nov., sp. nov., a new member of the family Bifidobacteriaceae isolated from the digestive tract of bumblebees. Syst. Appl. Microbiol. 2010, 33, 359-366. [CrossRef] [PubMed]

63. Wu, Y.; Ma, H.; Zheng, M.; Wang, K. Lactic acid production from acidogenic fermentation of fruit and vegetable wastes. Bioresour. Technol. 2015, 191, 53-58. [CrossRef]

64. Combes, S.; Ikken, S.; Gidenne, T.; Balmisse, E.; Aymard, P.; Gabinaud, B.; Segura, M.; Barilly, C.; Travel, A. Influence de l'ingestion précoce ou du ratio protéine amidon sur les performances de croissance et le microbiote caecal. Journ. Rech. Cunicole 2017, 17, $87-90$.

65. Zened, A. Particularités du Microbiote et son Activité Lors de la Déviation de la Biohydrogénation Ruminale de L'acide Linoléique de la Voie Trans-11 à la Voie Trans-10. Ph.D. Thesis, Toulouse University, Toulouse, France, 2011. Available online: http:/ / ethesis.inp-toulouse.fr/archive/00001711/ (accessed on 3 August 2020).

66. Wang, L.; Li, P.; Tang, Z.; Yan, X.; Feng, B. Structural modulation of the gut microbiota and the relationship with body weight: Compared evaluation of liraglutide and saxagliptin treatment. Sci. Rep. 2016, 6, 1-10. [CrossRef]

67. Cook, A.R.; Riley, P.W.; Murdoch, H.; Evans, P.N.; McDonald, I.R. Howardella ureilytica gen. nov., sp. nov., a Gram-positive, coccoid-shaped bacterium from a sheep rumen. Int. J. Syst. Evol. Microbiol. 2007, 57, 2940-2945. [CrossRef]

68. Gupta, R.S.; Chen, W.J.; Adeolu, M.; Chai, Y. Molecular signatures for the class Coriobacteriia and its different clades; proposal for division of the class Coriobacteriia into the emended order Coriobacteriales, containing the emended family Coriobacteriaceae and Atopobiaceae fam. nov., and Eggerthe. Int. J. Syst. Evol. Microbiol. 2013, 63, 3379-3397. [CrossRef]

69. Prins, R.A.; Lankhorst, A.; Van der Meer, P.; Van Nevel, C.J. Some characteristics of Anaerovibrio lipolytica, a rumen lipolytic organism. Antonie Van Leeuwenhoek 1975, 41, 1-11. [CrossRef]

70. Singh, K.M.; Pandya, P.R.; Tripathi, A.K.; Patel, G.R.; Parnerkar, S.; Kothari, R.K.; Joshi, C.G. Study of rumen metagenome community using qPCR under different diets. Meta Gene 2014, 2, 191-199. [CrossRef] [PubMed] 
71. Bhatta, R.; Uyeno, Y.; Tajima, K.; Takenaka, A.; Yabumoto, Y.; Nonaka, I.; Enishi, O.; Kurihara, M. Difference in the nature of tannins on in vitro ruminal methane and volatile fatty acid production and on methanogenic archaea and protozoal populations. J. Dairy Sci. 2009, 92, 5512-5522. [CrossRef] [PubMed]

72. Jenkins, T.C. Lipid metabolism in the rumen. J. Dairy Sci. 1993, 76, 3851-3863. [CrossRef]

73. Pantoja, J.; Firkins, J.L.; Eastridge, M.L.; Hull, B.L. Effects of fat saturation and source of fibre on site of nutrient digestion and milk production by lactating dairy cows. J. Dairy Sci. 1994, 77, 2341-2356. [CrossRef]

74. Mkhize, N.R.; Scogings, P.F.; Nsahlai, I.V.; Dziba, L.E. Diet selection of goats depends on season: Roles of plant physical and chemical traits. Afr. J. Range Forage Sci. 2014, 31, 209-214. [CrossRef]

75. Waghorn, G. Beneficial and detrimental effects of dietary condensed tannins for sustainable sheep and goat production-Progress and challenges. Anim. Feed Sci. Technol. 2008, 147, 116-139. [CrossRef]

76. Sawanon, S.; Koike, S.; Kobayashi, Y. Evidence for the possible involvement of Selenomonas ruminantium in rumen fiber digestion. FEMS Microbiol. Lett. 2011, 325, 170-179. [CrossRef]

77. Hocquette, J.; Picard, B.; Doreau, M.; Bauchart, D.; Micol, D. La viande des ruminants. De nouvelles approches pour améliorer et maîtriser la qualité. Viandes Prod. Carnés 2009, 24, 7-18.

78. Guo, B.; Li, D.; Zhou, B.; Jiang, Y.; Bai, H.; Zhang, Y.; Xu, Q.; Zhao, W.; Chen, G. Comparative characterization of bacterial communities in geese consuming of different proportions of ryegrass. PLoS ONE 2019, 14, e0223445. [CrossRef] [PubMed]

79. Alsaker, K.V.; Paredes, C.; Papoutsakis, E.T. Metabolite stress and tolerance in the production of biofuels and chemicals: Geneexpression-based systems analysis of butanol, butyrate, and acetate stresses in the anaerobe Clostridium acetobutylicum. Biotechnol. Bioeng. 2010, 105, 1131-1147. [CrossRef] [PubMed]

80. Lerma-Reyes, I.; Mendoza-Martínez, G.D.; Rojo-Rubio, R.; Mejia, M.; García-Lopez, J.C.; Lee-Rangel, H.A. Influence of supplemental canola or soybean oil on milk yield, fatty acid profile and postpartum weight changes in grazing dairy goats. Asian Australas. J. Anim. Sci. 2018, 31, 225-229. [CrossRef] [PubMed]

81. Vera, R.; Aguilar, C.; Lira, R.; Toro, P.; Barrales, L.; Peña, I.; Squella, F.; Pérez, P.; Quenaya, J.; Yutronic, H.; et al. Feeding dry olive cake modifies subcutaneous fat composition in lambs, noting cake resistance to degradation and peroxidation. Chil. J. Agric. Res. 2009, 69, 548-559. [CrossRef]

82. Wood, J.D.; Enser, M.; Fisher, A.V.; Nute, G.R.; Sheard, P.R.; Richardson, R.I.; Hughes, S.I.; Whittington, F.M. Fat deposition, fatty acid composition and meat quality: A review. Meat Sci. 2008, 78, 343-358. [CrossRef] [PubMed] 